\title{
EFL Teachers and Students' Perceptions of Enacting 'Teacher-in-role'
}

\author{
Sitti Fatimah \\ English Department \\ Faculty of Languages and Arts \\ Universitas Negeri Padang \\ Padang, Indonesia \\ sitti.fatimahbing@gmail.com
}

\begin{abstract}
Teacher-in-role is an element of process drama used in teaching learning processes. This article reports on research findings about EFL teacher and student participants' perceptions of teacher-in-role after the implementation of 'Mantle of the Expert' (MoE), a drama-based teaching approach, in Indonesian high schools. The findings demonstrate positive impacts on students and teachers' experiences during English instruction. Through a multi-case study I discovered that the teachers who took on a role (teacher-in-role) expressed excitement and indicated a new nuance in their teaching practices. I also found that the majority of students from two groups enjoyed teacher-in-role and viewed it as the technique to promote teaching and learning process as revealed in their responses to questionnaire. Despite few teacher-in-role trials conducted during the MoE implementation, both teacher and student participants preferred that this teacher-student collaboration in teaching and learning processes should be more frequently practiced.
\end{abstract}

Keywords - teacher-in-role; MoE; process drama; English instruction

\section{INTRODUCTION}

Although role-play has been familiar and widely implemented by many of Indonesian English teachers, teacher-in-role where the teacher gets involved in the role-play performed together with students - is not recognized in the classroom practices. However, this element of process drama has been well applied in teaching and learning process both in primary and secondary of European, Canadian, American, and Australian schools. This is seen in their school curriculum (for example, see Arts Council England (2003), Australian Curriculum Assessment and Reporting Authority (2011)). A number of studies revealed positive impacts of teacher-in-role on teachers' practices and student learning (for example, Housum-Stevens, 1998 and Piazzoli, 2010).

Teacher-in-role is one of the elements required when a teacher implements 'Mantle of the Expert' (MoE), a drama-based teaching approach initiated and promoted by Dorothy Heathcote. Through this article, written based on the results of my research undertaken to complete my PhD study, I highlight the discussion on the enactment, challenges and impacts of teacher-in-role on teachers' teaching experience and student learning during EFL teaching and learning processes at senior and vocational high schools. Within the frame of MoE, teacher-in-role was enacted by two English teachers; both of them taught English at two different senior high schools in Padang, Indonesia. However, perceptions from the vocational high school English teachers who did not enact teacher-in-role were also included in this article

\section{The Concept of Teacher-in-role}

Teacher-in-role is that the teacher takes on a role to place the students as those who are experts in a particular field of human knowledge in an imagined context (Heathcote \& Herbert, 1985). The idea was first introduced by Heathcote in 1970s when she declared MoE. Heathcote (Heathcote \& Bolton 1995) elaborates teacher's action when being in-role:

Teacher-in-role in MoE is a particularly mercurial version, with the teacher frequently engaged in hopping deftly, sliding elliptically, switching abruptly, or even bestriding the two worlds of fiction and reality. It may be just a matter of seconds that a role is held and then dropped - and then assumed again. It is even possible to convey with a word and the raising of an eyebrow a deliberate ambiguity between the two ( $p$. 30).

When not being in-role, the teacher is out-of-role "to design learning tasks that the context makes necessary to be undertaken" (Heathcote, 2008). This double function of the teacher during MoE practice is called metaxis. The teacher is termed as a maister if he/she is in role or inside the mantle. The maister is "responsible for providing, overseeing, and maintaining the momentum of the work as well as regulates behaviour, offers information in restricted code and builds belief in ongoing tasks of the enterprise" (Heathcote, 2002, p. 3). When being the maister, the teacher should also participate as a firm leader and establish the protocol of behaving "as if we are experts" that allows the students to shift the thinking and learning about things into that of thinking from within the matters of concern...the teacher's capability in doing this invokes students' self-awareness to endure the 
responsibility for "serving the needs of their clients..." (Heathcote, 2004, p. 5). Meanwhile, outside the mantle the teacher's function is only as a helper to make the enterprise run successfully and offer solutions. The teacher out-of-role never employs "the voice of the expert instructor" (Heathcote, 2002, p. 3).

Being both in and out-of-role, the teacher should constantly use inclusive language (we, us, etc.) in order to maintain the teacher-student and enterprise owner-client relationship. This relationship suggests a sharing or partnership between teacher and students. According to Abbot, in responding to Boschi's question, the application of MoE is "one where teacher is sharing the human space with kids, the teacher is not doing it to them...but is creating opportunities to do things with them" (Boschi, 2011, p. 69). This suggests mutual collaboration between teacher and students. By doing teacher-in-role, "pupils' personal development and well-being are at the core of learning in MoE" (Matusiak-Varley, 2011, p. 36). As such, as she continues, pupils develop life skills and responsibility. Through guidance from the teacher, pupils are led to solve problems while researching independently or participating in group tasks within the schedule given.

Heathcote clarifies that the teacher is independent in terms of having the competence to take on a number of roles, but s/he should be "someone who is dependent on the students' roles for advice and guidance about immediate tasks, but who has a strong sense of the firm's past history and of how things used to be done" (Heathcote \& Bolton, 1995, p. 24). In other words, the teacher should have the combined ability as a person who knows when to be in-role or out-of-role, and has sufficient knowledge about the whole idea of the selected enterprise, but has to continue inviting students' ideas, suggestion and advice; and to some extent has to rely them. Therefore, the teacher should never dominate the situation, whether s/he would either entertain the class or disempower them (Heathcote, 2008). Being in-role, the teacher actually adopts egalitarian concept as s/he "must share power to position the students (individually and collectively) as knowledgeable and competent colleagues and also ensure that children position one another similarly" (Anderson, 2012, p. 103). This means that the teacher and students work collaboratively throughout the MoE process in order to make the learning meaningful and purposeful. This kind of teaching and learning processes, which takes place when both teacher and students take on a role, promotes teacher-student interaction.

\section{Previous Studies involving Teacher-in-role}

A number of studies implementing teacher-in-role indicate significant benefits for teacher's practices and student learning. Teacher-in-role performed spontaneously by Housum-Steven (1998) transformed a formerly unconfident secondary student to a 'new-found' confident one. Almost similar to Housum-Steven's experience, Piazzoli (2010) observed that teacher-inrole she conducted increased her student's confidence to use spoken Italian language:

\section{“...Tina [Piazzoli's student] had adopted a new role, in an authentic context for communication, injected with dramatic tension. In that context, it was the power of the 'teacher in role' strategy that motivated her to engage in a meaningful, spontaneous interaction” (pp. 40-41).}

Unlike Housum-Steven's spontaneous role, Taylor (2002) felt uneasiness at the beginning. As Taylor performed teacherin-role more naturally, the primary students who were giggled at the beginning were carried away in the role-play and conducted as expected of them. Sayers (2011) found that being in-role through MoE teaching and learning allowed teachers to observe and develop students' language.

\section{METHOD}

The study was conducted according to the principles of constructivism. Constructivism, also called interpretivism or naturalism, is an approach that sees reality as social construction (Robson, 2002). Here, the role of the researchers is "to understand the multiple social constructions of meaning and knowledge... [that]... "will allow them to acquire multiple perspectives" (p. 27). Creswell (2009) emphasizes that those multiple perspectives are generated by "relying as much as possible on the participants' views about the situation being studied" (p. 28).

This study can be categorized as a multiple-case study because "each school [was] the subject of an individual case study, but the study as a whole [covered] several schools" (Yin, 2009, p. 53). Thus, the study involved three English teachers and 89 Grade 11 students from two senior high schools (one was public and the other one was private) and one vocational high school located in Padang city of West Sumatra Province.

The data were collected through several methods: 1) classroom observations for six lessons, 2) semi-structured interview with teacher participants during the implementation of $\mathrm{MoE}$ and focus group discussion before and after the implementation of $\mathrm{MoE}$, and 3) questionnaire distributed to student participants. These data were analyzed using Qualitative Content Analysis approach. This approach was used since the data comprised the content of language as communication obtained through the language communicated in focus group discussions and individual interviews with teachers, open-ended questions from the student questionnaire, and classroom interactions.

In coding my data, I applied the qualitative content analysis procedures suggested by both Mayring (2000) and Hsieh and Shannon (2005): deductive category application (directed content analysis) and inductive category development (conventional or classical content analysis). The process of data coding or of naming the categories in deductive category application is carried out 
by using ideas from either existing theories or prior research to categorize the text. To organize my data over the course of the coding process, I applied the matrix system proposed by Miles and Huberman (1994).

\section{FINDING AND DISCUSSION}

Of the three teacher participants involved in the study, only two had confident to perform teacher-in-role. Thus, this section only discusses the perceptions from those two teachers (Umaira and Rossa) and their respective students.

\section{Umaira and her students}

Umaira had a pre-existing interest in using role-plays as a pedagogical strategy and reported having often used a roleplay as a pre-teaching activity to engage students with a lesson or as a way to engage students more deeply in their learning. She explained, "If you can perform the text well, that mean[s] you can comprehend the text well" (Umaira, Pre-MoE Workshop/Training Interview). Although Umaira said that she liked drama, in the sense of involving role-plays in her teaching practices, the idea of taking on a role with students, particularly within MoE, was a completely new concept for her.

Umaira took on a role only in Lesson Two when she was in-role as the Minister. This first experience was challenging for her as she stated: “It's hard for me. I will be Minister [/as/] my student [s] want to. So, [I] ask, in what role? I don't know. It's hard for me to be the expert" (Umaira, Semi-Structured Interview 1).

The challenge of being in-role for Umaira was not only because it was her new teaching experience, but it also required her knowledge of the role she was assigned. She had a struggle to be the expert situated within the imagined $L P K$. It seemed that because of her challenging first experience, from Lesson Three through to Lesson Six, Umaira tended to remain out-of-role even when her students were diligently working in-role. At the same time, Umaira expressed her ambiguity about the concept of teacher-in-role. Umaira claimed to prefer remaining out-of-role rather than taking on a role because she thought that it would be more useful for students:

I think, like before, I will make clarification to make my student understand more. I help them; only that's my involvement now, not like Mantle of [the] Expert you want to [what she did in terms of teacher-in-role was unlike required by Mantle of the Expert] (Umaira, Semi-Structured Interview 1).

Umaira argued that by remaining out-of-role as the teacher, she would be better able to assist students by explicitly teaching the concepts they would have to apply before they took on a role. Her participation was limited to helping students when she and students were out-of-role. Umaira retreated from taking on a role as she was concerned that students' focus would be diverted if she entered the role-play (Classroom Observation Notes, Udayana SHS, Lesson Two).

Later in the MoE implementation period, Umaira became willing to take on a role; but, it was the students who refused her. She said, “... I've been only once involving in the group because they don't allow me” (Umaira, Semi-Structured Interview 2). Umaira wanted to take on a role because she was beginning to enjoy it and feel more confident with MoE and she understood that $\mathrm{MoE}$ required her involvement with student-in-role. But, by the time she was ready to participate in-role, her students were deeply engaged in their role-plays. Furthermore, they did not understand that teacher-in-role was part of MoE since Umaira had only modeled this in Lesson Two and did not explain about it to the students.

Umaira's initial feelings about teacher-in-role indicated a tension between her sense of responsibility to help students engage with their learning and the expectation to take on a role herself, as required by MoE. Her first teacher-in-role experience provided her with the difficulty of doing it. This led her to decide to stay back. However, after trialling MoE simultaneously in three classes (11NS5, 11NS6 and 11NS7), and experiencing an interesting teacher-in-role in 11NS6 class (non-MoE student participants) (as she said: “...that's funny, the experience was interesting, she gained confidence and was willing to take on a role with 11NS5 students (MoE student participants). At the same time, the students of 11NS5 had grown used to having more control over their own learning; and with increased self-confidence, they preferred not to include Umaira into their role-play. Umaira did not impose her authority over her students. Rather, she remained out-of-role but adopted a stance as a facilitator of student learning, instead of an instructor.

While Umaira's perceptions about teacher-in-role were to some extent positive but also contained tension, the majority of her students considered it beneficial for their learning. Of the 29 students, a total of 11 students $(38 \%)$ perceived that teacherin-role increased their own enjoyment and engagement as students. One observed: "I'm very enthusiastic, I like it". Ten others $(34 \%)$ believed that when Umaira was in-role with them, she could direct the role-plays and better control students and facilitate their learning. For example, one explained that, "The teacher can participate in drama so that the drama runs better". Five students $(17 \%)$ commented on how the teacher-in-role could build closer relationship with them. For example, one said that teacher-in-role is "very good because it can make teacher-student relationship closer". Two students (7\%) responded that teacher-in-role provided an opportunity for students to learn spoken English. One of them responded that, "I think it's good because we can learn to speak English well and accurately". Only one student (3\%) attributed the benefits of teacher-in-role to the teacher's own fulfillment in teaching. The student wrote, "It's good for teacher because I think teacher must like it". 


\section{Rossa and her students}

Initially, Rossa believed that it was not easy for her to take on a role. She explained:

I think it's quite difficult because I haven't established an institution. Also, I'm thinking in the classroom how to go to [DEP]DIKNAS, and then, what will they do... and what they are going to do. I don't know because I haven't gone to [DEP]DIKNAS. I don't know the room, what they are doing in the room. I haven't seen that ... (Rossa, Semi-Structured Interview 1).

The above statement was Rossa's prediction about the difficulty of being in-role as the staff of DEPDIKNAS who was in charge of reviewing the $L P K$ proposal. Rossa thought that to be in-role in a context where she did not have the knowledge about was a great challenge although finally the presenting group chose other group to be in-role as the DEPDIKNAS staff member.

However, after four lessons of using MoE, Rossa found herself feeling 'comfortable' (Rossa, Semi-Structured Interview 3) when taking on a role in small group discussion and reflected that it provided benefits to the student learning process and to her own teaching practices. First, she realized that teacher-in-role was important to engage herself with students' activities so as to enhance their engagement:

...I participated in the drama, in-role in their group discussion [about making a brochure]. That's the drama point. That's the point there. And in the previous one [previous instruction prior to MoE], I didn't participate in their discussion. I only asked them to do A, B, C or D. And I only pay attention to them, not join in their group... [now] I sit with them. I join there as the member in that group also. [I] pretend that I am from Pariaman [one branch of LPK]. And I think that's a good point there. I [was taking] on a role in the drama, not like the previous one. So, I would like to give them more explanation there. What should we do? We should do what? What is the difference one to make? (Rossa, Semi-Structured Interview 2).

This comment suggests that teacher-in-role was a new teaching experience for Rossa's close involvement in student discussion when completing a task. She had not used this kind of instructional strategy before; she had previously only set instructions and watched students completing their task. According to her comments, Rossa saw how involvement in the roleplay, by playing the role of a staff member of the $L P K$, allowed her to provide students with further explanation about the lesson and activity in a way which both motivated their engagement and encouraged their independent thinking. Rossa explained further how being in-role allowed her to push her students' thinking and engagement: "I would like to give them more motivation there. So, I have to give more stress [emphasis], I have to give more explanation to them. They have to do this" (Rossa, Semi-Structured Interview 2). Rossa's experience with teacher-in-role gave her the opportunity to offer more explanation to the students which she believed made them more motivated, and helped them to understand the lesson better and engage more with the learning process. Just as important as being involved through teacher-in-role was the nature of Rossa's involvement. She did not directly instruct the students but asked questions which invited them to discuss the activity in more depth. The way Rossa used the pronoun 'we' when asking questions of the students is reflective of Heathcote's approach to leading MoE, both in-role and out of role. Through this kind of discussion and attitude to building interaction with the students, Rossa encouraged them to explore their own ideas and develop their own solutions to problems, rather than simply accepting ideas from her as the teacher.

Being in-role as the teacher allowed Rossa to develop and feel a new kind of connection with her students. She explained:

How can I say ... that's good, having participation in the group. They pretend me not as their teacher at that time, but as their friend... Not like the previous one, I only ask, do this, this, this and present this, this, this... [I was only] the witness (Rossa, Semi-Structured Interview 2).

Rossa liked the fact that the students felt close to her. Later, Rossa confirmed her sense that when teacher and students took on a role together, they became closer to each other, explaining that "...we are getting in role in the discussion, in drama with the students. And so there is no gap between teacher and students. That's good." (Rossa, SemiStructured Interview 3). Rossa saw that this new form of relationship, which was made possible by the imaginary context of role-play, had the potential to further enhance student engagement by creating an egalitarian relationship between teacher and student in which there was "no gap," as opposed to the more hierarchical relationship that is encouraged by traditional forms of instruction.

Quite similar to what Umaira's students experienced, all of Rossa's students expressed positive responses about their experience with Rossa as teacher-in-role during MoE implementation. Their positive responses were varied. i) A total of 15 students $(58 \%)$ perceived that working with the teacher-in-role increased their enjoyment as students so that they became more engaged. ii) A total of 10 students (38\%) viewed that having the teacher-in-role was helpful as she could become a source of additional information. iii) One student (4\%) believed that through teacher-in-role, Rossa built a closer relationship with students: 


\section{Discussion}

If the enactment of teacher-in-role performed by Rossa compared to Umaira, Rossa appeared to find the adoption of teacher-in-role to be easier than Umaira. This is evident in the fact that she chose to enact teacher-in-role more often than the others, and she identified fewer associated challenges. But, even for Rossa, the public performance aspect of adopting teacher-inrole was initially challenging due to what she acknowledged as her lack of knowledge about the role she adopted within the enterprise she had established. She realized that she did not know very much about the duties and responsibilities of staff who work at DEPDIKNAS; thus, in her role as a DEPDIKNAS staff member reviewing proposals, she was uncertain about what to say in order to play the part as quoted above.

Significantly, Rossa adopted what Heathcote described as a 'middle-rank role' (Wagner, 1976, p. 128) and what Ewing and Simons (2004) call 'a second-in-charge role', as a member of the LPK staff. Heathcote and others emphasize the importance of teachers taking on middle-rank roles so that they do not control the role-play. It is a technique designed to ensure that teachers share power and control of the direction of the role-play with their students. From Wagner's observation, Heathcote recommends that a teacher should take the middle-rank position because s/he in the position to "communicate freely to those of both higher and lower rank. S/he can impose the limits that create tension and even work to raise a group to a feverish pitch of anger against her/him" (as cited in Wagner, 1976, p. 129). Ewing and Simmons (2004) have a similar view, affirming the adoption of the middle-status role for a teacher because s/he can adjust herself/himself with the students. This was evident in that the high-status role that Rossa adopted as a DEPDIKNAS staff member had required her to take primary responsibility for driving the role play, while in her middle-rank role as an $L P K$ staff member, she did not. But what is more significant in Rossa's case is that her adoption of a middle-rank role had the additional benefit of alleviating some of her nervousness and anxiety about being in role. For teachers working with MoE for the first time, this side-benefit of adopting a middle-rank role is significant and might make it easier for them to experiment with teacher-in-role despite their uncertainty about adopting this unfamiliar pedagogical approach.

While Rossa was reluctant about taking on a high-status role during public role-play performances, Umaira willingly agreed to her MoE participating students' request to take on the public performance role of the Minister and to determine which of their proposals should be approved or rejected. Like Rossa, Umaira also expressed difficulties around performing a public performance role-play. She, too, admitted that she lacked knowledge about the job and responsibilities of the Minister. She did not really know what she would say and had to ask for suggestions from a student who was in-role with her.

Heathcote (2008) emphasized that when the teacher takes on a role in an enterprise, it is essential that s/he should have good knowledge of the enterprise. Both Rossa and Umaira experienced difficulties in taking on roles precisely because they had little knowledge about them. This indicated that they had not considered their own role-playing as part of their MoE lesson planning. This is evident when examining their lesson planning documents (or what DEPDIKNAS refer to as RPP) in which they did not include any information about how they planned to participate in role-plays. Sayers (2014) points out that "MoE is simple to set up in the classroom but complex to prepare" (p. 13) and this was evident in Rossa and Umaira's failure to plan for the complex task of taking on a role with students.

\section{CONCLUSION AND RECOMMENDATION}

Teacher involvement in role-play or being in-role has demonstrated the shift of teacher's role from being only a teacher to a facilitator and co-learner. In these roles, they appeared to work alongside their students and relinquished some of the dominant and directive teaching approaches they had traditionally adopted. During this activity, students no longer perceived their teacher as a figure to be scared of; instead, they looked upon them as their partner in learning. The sustainability of teacher-in-role enactment is believed to enhance teaching and learning processes that potentially lead to meaningful teaching and learning experience

\section{References}

Anderson, M. (2012). MasterClass in Drama Education: Transforming teaching and learning. London: Continuum International Publishing Group.

Arts Council England. (2003). Drama in schools. 2nd. Retrieved from http://www.artscouncil.org.uk/media/uploads/documents/publications/725.pdf

Australian Curriculum Assessment and Reporting Authority (ACARA). (2011). Shape of the Australian curriculum: The arts. Retrieved from: http://www.acara.edu.au/verve/ resources/Shape of the Australian_Curriculum_The Arts Compressed.pdf

Boschi, R. L. (2011). Mantle of the Expert: Potentialities of this method in the Brazilian educational system. (Master's Thesis), London. Retrieved from http://www.mantleoftheexpert.com/wp-content/uploads/2008/03/Dissertation-Final-versionwith-front-page.pdf

Ewing, R., \& Simons, J. (2004). Beyond the script: Drama in the classroom, take two. Newtown: Primary English Teaching Association.

Heathcote, D., \& Bolton, G. (1995). Drama for learning: Dorothy Heathcote's Mantle of the Expert approach to education (O. N. Cecily Ed.). Portsmouth, NH: Heinemann. 
Heathcote, D., \& Herbert, P. (1985). A drama of learning: Mantle of the expert. Theory into Practice: Educating through Drama, 24(3), 173-180. doi:10.1080/00405848509543169

Heathcote, D. (2002). Contexts for active learning-Four models to forge links between schooling and society. The Journal for Drama in Education, 19(1), 1-14. Retrieved from http://perswww.wlv.ac.uk/ in5127/natdtest/journal\%20backcopies.html

Heathcote, D. (2004). 30 years in the making: 1974-2004. Retrieved from http://www.moeplanning.co.uk/wpcontent/uploads/2008/04/dh-mantle-of-the-expert.pdf

Heathcote, D. (2008). Mantle of the Expert: A further paradigm for education? New Zealand Journal of Research in Performing Arts and Education, 1, 1-12.

Housum-Stevens, J. B. (1998). Performance possibilities: Curating a museum. Voices From the Middle, 6(2), 19-26. Retrieved from http://search.proquest.com.ezproxy.lib.monash.edu.au/eric/docview/213929912/fulltextPDF/135D6CCF0F8199231AA/2 ?accountid $=12528$

Hsieh, H.-F., \& Shannon, S. E. (2005). Three Approaches to Qualitative Content Analysis. Qualitative Health Research, 15(9), 1277-1288. doi:10.1177/1049732305276687

Matusiak-Varley, B. (2011). Developing pupil's learning through the use of Mantle of the Expert. In S. Schonmann (Ed.), Key concepts in Theatre/Drama Education (pp. 35-38). Rotterdam: Sense Publishers.

Mayring, P. (2000). Qualitative content analysis. Forum: Qualitative Social Research, 1(2). Retrieved from http://www.qualitative-research.net/index.php/fqs/article/view/1089

Miles, M. B., \& Huberman, A. M. (1994). Qualitative data analysis: An expanded sourcebook (2nd ed.). Thousand Oaks, Los Angeles: Sage Publications.

Piazzoli, E. (2010). The power of 'Teacher in Role'. Modern Language Teachers' Association of Queensland, 149, 39-41.

Sayers, R. (2011). The implications of introducing Heathcote's Mantle of the Expert approach as a community of practice and cross curricular learning tool in a primary school. English in Education, 45(1), 20-35. doi:10.1111/j.17548845.2010.01084.x

Robson, C. (2002). Real world research (2nd ed.). Oxford: Blackwell Publising Ltd.

Taylor, P. (2000). The drama classroom: Action, reflection, transformation. London: Routledge Falmer.

Wagner, B. J. (1976). Dorothy Heathcote: Drama as a learning medium. London: Hutchinson.

Yin, R. K. (2009). Case Study Research: Design and Methods (4th ed. Vol. 5). Thousand Oaks: Sage Publications, Inc. 